\title{
POPULATION FLUCTUATION OF THRIPS, WHITEFLY AND ASSOCIATED PREDATORS IN CABBAGE PLANTATIONS AS INFLUENCED BY WEATHER FACTORS AND TOXIC COMPOUNDS
}

\author{
El- Fakharany, Sanaa K. M. \\ Plant Protection Research Institute, ARC, Dokki , Giza, Egypt
}

\begin{abstract}
Field experiments were conducted during two successive cabbage growing seasons (2008/09 and 2009/10) at El-Riad district, Kafr El-Sheikh Governorate. The objective was to study the population fluctuation of thrips, Thrips tabaci Lind., whitefly, Bemisia tabaci (Genn.) and their predators (Chrysoperla carnea and true spiders) in cabbage plantations. The toxicity of Marshal and Bermectine in reducing the population density of $T$. tabaci and $B$. tabaci infesting cabbage was evaluated. Also, the side effect of these compounds on Chrysoperla carnea and true spiders was assessed. Beside the effect of weather factors (mean temperature, relative humidity and wind velocity). Population fluctuations of $T$. tabaci reached maximal abundance in March and early April in both seasons .B. tabaci was the earliest insect, among sucking pests, to attack cabbage plants, the population fluctuations reached maximal abundance in September and October in the both seasons. Highest abundance of $C$. carnea occurred in early November and April in the first season while it occurred in January and February in the second season. In both seasons, the maximum number of true spiders was detected in October and April. Temperature had a highly significant negative effect on thrips infestations, while wind velocity had a highly significant positive correlation with thrips in the first season. Whitefly tended to increase with an increase in the median temperature. True spiders correlated highly significant and negatively with whitelfy in the first season. The joint effect of weathering factors and predators on the populations of thrips and whitefly was higher in first season than in second season. Marshal and Bermectine under field conditions caused reduction in infestation of $T$. tabaci. The effects of both compounds on whitefly (mature and immature stages) were high to moderate. Concerning the side effects on the predators, Marshal induced moderate effect while Bermectine exhibited a slight effect against $C$. carnea and true spiders.
\end{abstract}

\section{INTRODUCTION}

Cabbage, Brassica oleracea var. capitata Linneu, cultivated worldwide, is attacked by pests such as thrips, Thrips tabaci Lindeman (Thysanoptera:Thripidae) and whitefly, Bemisia tabaci (Gennadius ) (Hemiptera : Aleyrodidae ). (Farrag and Zakzouk, 2000, Leite et al.,2005 and 2006 and Mahmoud et al.,2009). These insects weaken the plant by sucking the sap and introducing toxins into the plants vascular system, coating the leaf with honeydew, facilitating the growth of soot mold, and producing white streaking disorder, leaf chlorosis and leaf wrinkling. Thrips and whitefly cause direct damages to crops through feeding on plants sap and transmission of harmful plant viruses. Insects attacking cabbage are controlled by blanket spraying with foliar insecticides. The frequency of insecticide applications is determined by the degree of damage, which is heavily influenced by cosmetic considerations (Leite et al.,2006). 
Several factors such as climatic conditions, predators and certain chemical compounds can influence insect population on plants ( Horowitz, 1986, Hook et al., 1998, Abo- Sholoa, 2001, El-Naggar et al., 2006 and Leite et al.,2005 and 2006). However, these factors have been little studied in cabbage.

The objectives of this study are to correlate abundance of predators (C. carnea and true spiders) and weather factors with abundance of $T$. tabaci and B. tabaci attacking cabbage under field conditions. Also, efficiencies of Marshal and Bermectine in reducing the population density of T. tabaci and B. tabaci infesting cabbage plants and their side effects on $C$. carnea and true spiders.

\title{
MATERIALS AND METHODS
}

\author{
1-Population fluctuation of sucking pests and their predators in \\ cabbage plantations : \\ Population fluctuations of Thrips tabaci, Bemisia tabaci, Chrysoperla
} carnea and true spiders on cabbage (Brassica oleracea var. capitata Linneu) were investigated. Field experiments were carried out at El- Riad district, Kafr El- Sheikh Governorate during two growing seasons ; 2008/09 and 2009/10. Cabbage seedlings were sown on August $15^{\text {th }}$, November $20^{\text {th }}$ and February $26^{\text {th }}$ on both seasons. An area of about one half feddan was divided into four equal plots, and considered as four replicates. Inspection started 30 days after sowing, and continued weekly till the end of the crop season. Numbers of thrips (nymphs and adults) and whitefly (adults) were counted in the field on ten leaves/replicate in the morning (7-9 am). The same samples were taken the laboratory to count the number of immature stage of whitefly using binocular microscope. C. carnea (eggs, larvae and adults ) and true spiders (mobile stages ) were also counted on ten plants/ replicate in the field. The obtained numbers were transformed as square roots.

\section{2- Climatic factors :}

The daily mean temperature, daily relative humidity and wind velocity were supplied by the Meteorological Department at Sakha Agricultural Research Station.

3- Toxicity of the tested compounds against thrips, whitefly, Chrysoperla carnea and true spiders :

Toxicological studies were carried out at a field of cabbage (one half feddan) at El- Riad district, Kafr El- Sheikh Governorate during 2008/09 and 2009/10 seasons. The tested compounds were applied at recommended doses using a knapsack sprayer with one nozzle. These compounds were sprayed on March $26^{\text {th }}(2008 / 09)$ and April $2^{\text {rd }}(2009 / 10)$ of thrips and October $9^{\text {th }}(2008 / 09)$ and September $25^{\text {th }}(2009 / 10)$ for whitefly. Every treatment was replicated four times, in addition to an untreated area to act as check. The experiment was designed in a complete randomized block design. The tested compounds and rate per 100 litters water were as follows: 
A. Pesticide : Carbosulfan (Marshal) $25 \%$ WP at $150 \mathrm{~g} / 100 \mathrm{~L}$ water.

B. Biopesticide : Abamectin (Bermectine) $1.8 \% \mathrm{EC}$ at $40 \mathrm{ml} / 100 \mathrm{~L}$ water.

Pre - treatment counts of T. tabaci (nymphs and adults), whitefly (immature and adults), Chrysoperla carnea (larvae) and true spiders (mobile stages) were recorded before spraying at 40 cabbage leaves for thrips and whitefly, but for 40 cabbage plants for predators for each treatment. Posttreatment counts were recorded 1, 3, 5, 7, 10 and 14 days after applications. These leaves were kept in a paper bag and were immediately examined by using a binocular microscope in the laboratory to count the number of nymphs and pupae of the whitefly. Percentage of reduction was calculated according to Henderson and Telton ( 1955 ) equation.

\section{RESULTS AND DISCUSSION}

\section{1-Population fluctuation of sucking pests and their predators :}

Data illustrated in Figure (1) show the populations density of Thrips tabaci started to appear by the second week of December (2008/09) and the first week of October (2009/10). In $2008 / 09$, the peaks were recorded on December $18^{\text {th }}$, February $19^{\text {th }}$ and March $26^{\text {th }}$, while they were recorded on October $16^{\text {th }}$, December $18^{\text {th }}$ and April $9^{\text {th }}$ in the second season (in agreement with Leite et al.,2005 and 2006). It reached its maximal abundance on March and April in both seasons (Fig.1). Similar results were reported by Kimberly and Anthony (1988), Ibrahim and Adesiyun (2009).

Population density of whitefly are presented in Fig. (2\&3). This insect pest was the earliest to appear among sucking pests, to attack cabbage plants in $2008 / 09$ and 2009/10 seasons. Two whitefly peaks were recorded in each season. In the first season, the dense population of whitefly (adults) was recorded on October $16^{\text {th }}$ and November $6^{\text {th }}$, while they were recorded on September $25^{\text {th }}$ and March $5^{\text {th }}$ in the second season. Population density of whitefly (immature) was recorded on October $\left(16^{\text {th }}\right.$ and $\left.30^{\text {th }}\right)$ in $2008 / 09$ season and November $20^{\text {th }}$ and April $23^{\text {th }}$ in $2009 / 10$ season. Similar results were reported by Seham et al.( 1997), Farrag and Zakzouk (2000), Nassef et al. ( 2000) and El- Fakharany (2005). Leite et al. (2006) found that whitefly population tended to proliferate in the final stage of plant or reached a peak of population about 40 days after plantation.

Population densities of the considered predators are presented in Fig.(4\& 5). The true spiders were more abundant than Chrysoperla carnea, and exhibited four peaks during the two seasons of study, on October $23^{\text {th }}$, November $6^{\text {th }}$, January $29^{\text {th }}$ and April $9^{\text {th }}$ in the first season and on December $18^{\text {th }}$, January $15^{\text {th }}$, March $5^{\text {th }}$ and April $16^{\text {th }}$ in the second one. In the first season, the dense population of true spiders was recorded on October $\left(16^{\text {th }}\right.$ and $\left.30^{\text {th }}\right)$, January $8^{\text {th }}$ and April $30^{\text {th }}$. These peaks occurred on September $25^{\text {th }}$, December $4^{\text {nd }}$, January $15^{\text {th }}$, March $5^{\text {th }}$ and April $30^{\text {th }}$ in $2009 / 10$ season. 


\section{El- Fakharany, Sanaa K. M.}

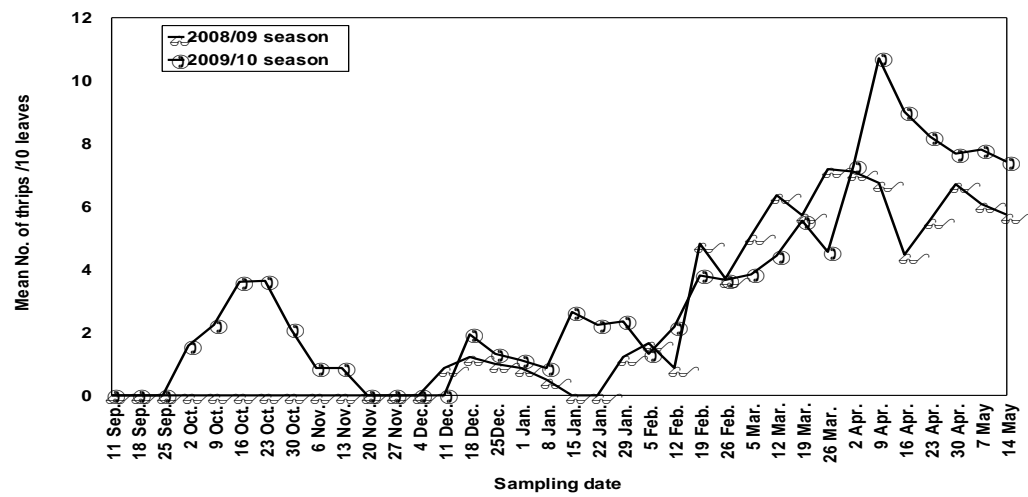

Fig. (1): Population fluctuation of Thrips tabaci( nymphs and adults )on cabbage plants at El-Riad district, Kafra El-Sheikh Governorate .

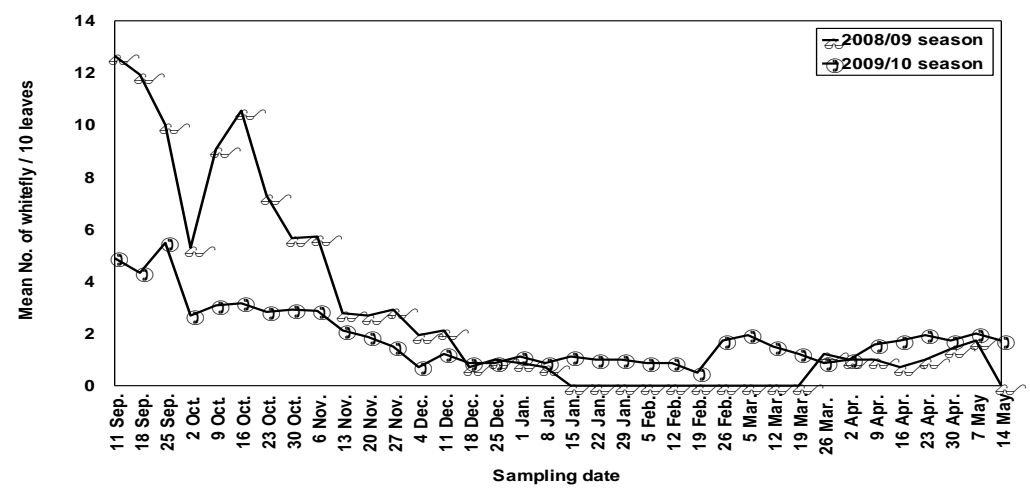

Fig. (2 ): Population fluctuation of Bemisia tabaci (adults) on cabbage plants at El-Riad district, Kafra EI-Sheikh Governorate

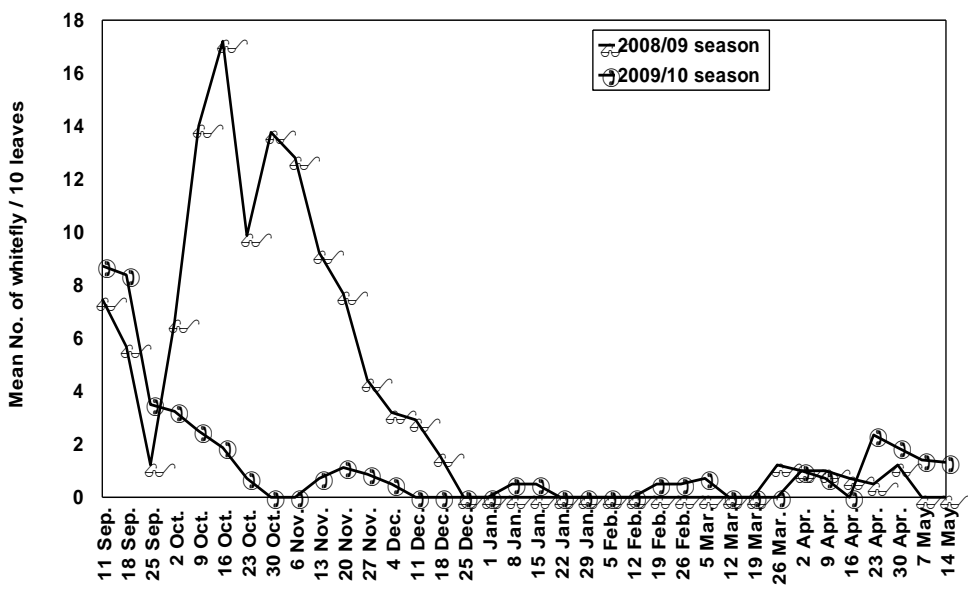

Sampling date

Fig. (3 ) : Population fluctuation of Bemisia tabaci ( immature ) on cabbage plants at El-Riad district, Kafra El-Sheikh Governorate . 


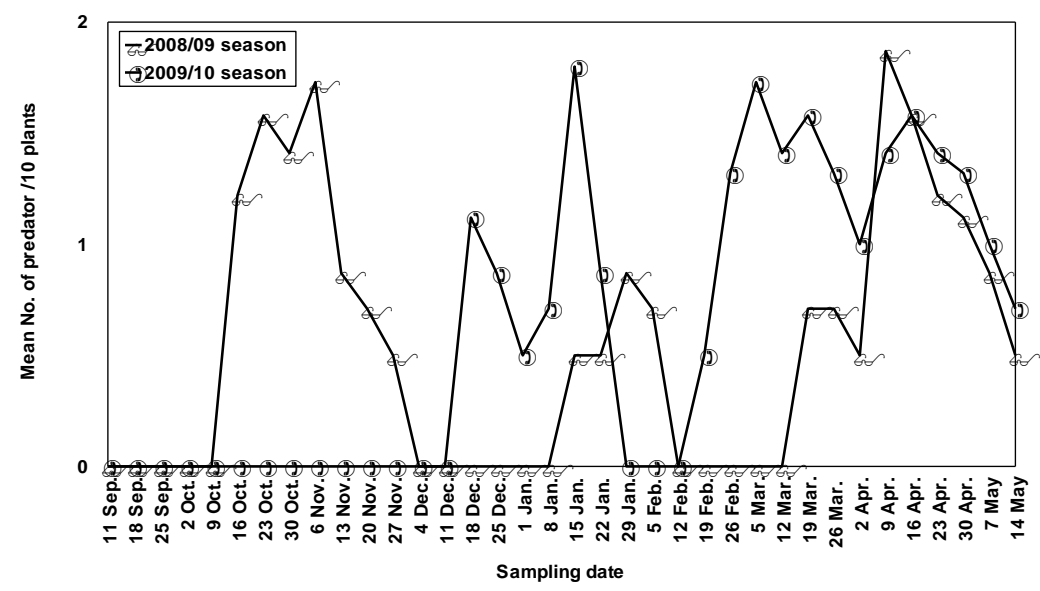

Fig. (4 ) : Population fluctuation of Chrysoperla carnea( immature and adults) on cabbage plants at El-Riad district, Kafra El-Sheikh Governorate .

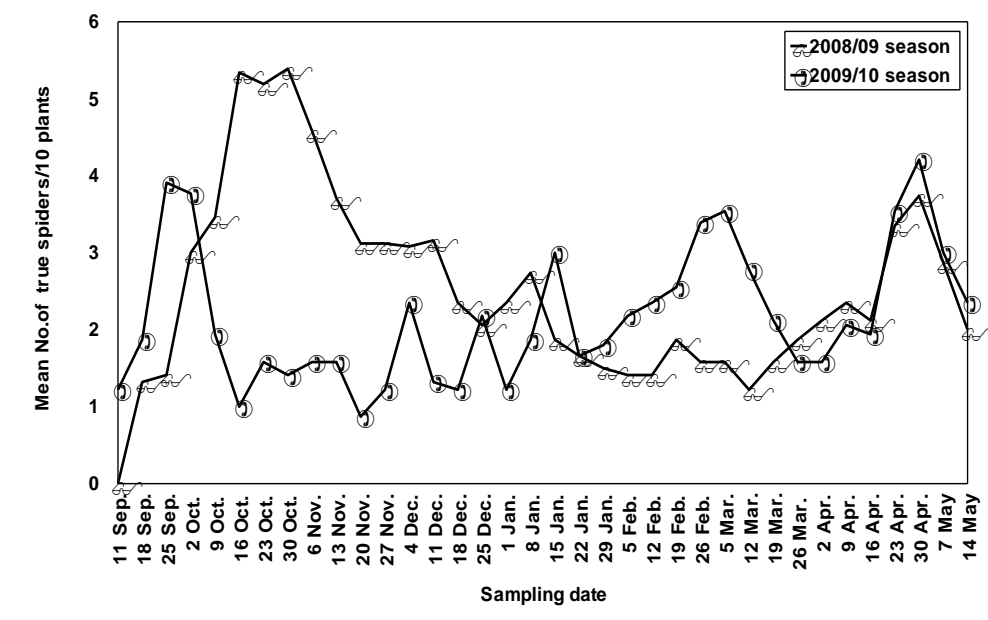

Fig. (5 ) : Population fluctuation of true spiders ( spiderlings and adults ) cabbage plants at El-Riad district, Kafra El-Sheikh Governorate .

\section{2- Effect of climatic factors and predators on thrips and whitefly : Thrips tabaci :}

Data in Table (1) showed that the temperature induced highly significant negative effect in 2008/09, insignificant positive in 2009/10 (in agreement with El-Fakharany,2005). Relative humidity had an insignificant negative effect in 2008/09 and an insignificant positive effect in 2009/10 season. Wind velocity had a highly significant positive effect in 2008/09 season and an insignificant positive effect in the second season. Hamdy and Salem (1994) found that correlation between onion thrips and temperature was significant and positive while it was significant and negative with relative humidity. 


\section{El- Fakharany, Sanaa K. M.}

\section{Bemisia tabaci}

The temperature had a highly significant positive effect on $B$. tabaci population in both seasons. Seham et al. (1997), Nassef et al. (2000), AboSholoa (2001), El-Fakharany (2005) and Leite et al. (2006) found that whitefly population tended to increase with increase of temperature. Relative humidity had an insignificant positive effect in both seasons ( Nassef et al., 2000 and El-Fakharany, 2005).Wind velocity had an insignificant negative effect in $2008 / 09$ season and an insignificant positive effect in 2009/10 season.

C. carnea population insignificantly negative correlated with $B$. tabaci population in both seasons. While true spiders had a highly significant negative effect in 2008/09 season and insignificant negative effect in the second season (Table,1).

Table (1): Partial correlation ( $r$ ) and regression coefficient (B) between climatic factors, predators and the population of Thrips tabaci and Bemisia tabaci on cabbage at El-Riad district, Kafr ElSheikh Governorate .

\begin{tabular}{|c|c|c|c|c|c|c|c|}
\hline \multirow[t]{2}{*}{ Season } & \multirow[t]{2}{*}{ Variables } & \multicolumn{3}{|c|}{ Thrips tabaci } & \multicolumn{3}{|c|}{ Bemisia tabaci } \\
\hline & & $r$ & B & E.V\% & $\mathbf{r}$ & B & E.V\% \\
\hline \multirow{5}{*}{$\begin{array}{l}\text { ㅇ } \\
\text { ᄋ̊ } \\
\text { ᄋ్ర }\end{array}$} & Mean temperature $\left(c^{\circ}\right)$ & -0.5190 & -2.329 & \multirow{5}{*}{61.60} & 0.6760 & 17.197 & \multirow{5}{*}{69.60} \\
\hline & Mean R.H( \%) & -0.1624 & -0.570 & & 0.2499 & 4.369 & \\
\hline & Wind velocity (m/h) & 0.6803 & 0.559 & & -0.1629 & -0.486 & \\
\hline & Chyrsoperla carnea & 0.2861 & 4.583 & & -0.2705 & -21.076 & \\
\hline & True spiders & -0.3762 & -0.760 & & -0.6887 & -8.684 & \\
\hline \multirow{5}{*}{$\stackrel{\text { 응 }}{\text { 옹 }}$} & Mean temperature $\left(c^{\circ}\right)$ & 0.2317 & 1.552 & \multirow{5}{*}{39.00} & $0.5634^{* *}$ & $3.469^{* *}$ & \multirow{5}{*}{40.40} \\
\hline & Mean R.H ( \%) & 0.1888 & 1.095 & & 0.0906 & 0.404 & \\
\hline & Wind velocity (m/h) & 0.2868 & 0.366 & & 0.0786 & 0.0753 & \\
\hline & Chyrsoperla carnea & 0.3258 & 10.645 & & -0.1145 & -2.779 & \\
\hline & True spiders & 0.0076 & 0.0407 & & -0.1177 & -0.497 & \\
\hline
\end{tabular}

3- The combined effect of temperature, relative humidity, wind velocity and predators on thrips and whitefly :

In general, the combined effect (percentage of explained variance) in Table (1) of the four factors on thrips and whitefly was higher in the first year $(61.60$ and $69.60 \%$, respectively) than in the second one (39.00 and $40.40 \%$, respectively). Nassef et al. (2000) and Ibrahim (2002) indicated into the important role of climatic factors and predators, that influenced population densities of pests.

\section{Follow - up the potency of compounds :}

The effect of the tested compounds on $T$. tabaci and B. tabaci infesting cabbage plants at El- Riad district, Kafr El- Sheikh Governorate is presented in Tables (2,3).

Thrips tabaci :

Data revealed that Bermectine was the most potent compound in reducing the population density of thrips during 2008/09 and 2009/10 seasons, with reductions (grand average ) of 95.84 and $96.75 \%$, respectively. It was followed by Marshal with reductions of 95.64 and 96.47 $\%$, respectively. 
J. Plant Prot. and Path., Mansoura Univ., Vol. 1 (11), November, 2010 2 
El- Fakharany, Sanaa K. M.

3

892 
Generally, biopesticide (Bermectine) exhibited high effectiveness. These results agree with the findings of Omar and El-Kholy (2001), El- Fakharany (2005 ), Thungrabeab et al. (2006), Mahmound and Osman (2007) and Mahmound et al. (2009).

\section{Bemisia tabaci :}

Conceming whitefly, data obtained in Table (3) show that Marshal induced the highest initial effect, exhibiting 83.50 and $81.40 \%$ reduction on mature stage and 84.00 and $84.50 \%$ reduction on immature stager during $2008 / 09$ and $2009 / 10$ seasons, respectively. However, it gave a moderate residual effect during the two seasons, it exhibited 64.64 and $62.76 \%$ reduction against mature stage, respectively. El- Naggar et al. (2006) found that the effect of Marshal on whitefly (adults and immature stages) was moderate. Ismail et al. ( 1998) reported that Marshal was effective against mature and immature stages of whitefly in the field. On the other hand, Bermectine gave moderate initial effect exhibiting 70.01 and $69.80 \%$ reductions against adults and 75.00 and $74.00 \%$ reductions against immature stage respectively, during the two seasons. It induced residual effects of 68.28 and $65.48 \%$ for adults and 74.90 and $71.79 \%$ in the immature stage in the two seasons respectively. Similar results were reported by El- Bessomy et al. ( 1997) and Horowitz et al. (1997).

5. Side toxic effects of Marshal and Bermectine Chyrsoperla carnea and true spiders inhabiting cabbage plantations :

The results recorded in Table (4) revealed that Marshal induced a moderate effect against predators, while Bermectine gave a slight effect in the two seasons. The present results are in agreement with the finding of Sharaf et al. ( 2003), El- Fakharany (2005) and El- Naggar et al. (2006). The results showed that biopesticide was safer to associated predators than pesticide.

\section{Conclusions}

1-The highest abundance of thrips on cabbage was detected in March and early April, while that of whitefly was detected earlier .B. tabaci was the earliest insect to appear among sucking pests on cabbage plants.

2- B. tabaci can be a harmful pest in cabbage cultivated in regions of high temperature. A joint effect of weathering factors and predators was found more remarkably on the density of thrips and whitefly in 2008/09 than 2009/10 seasons. Predators, especially the true spiders seemed to be important controlling agents of the $B$. tabaci population in cabbage.

3- Marshal and Bermectine caused more reduction in infestation with thrips than with whitefly in cabbage. Marshal induced moderate effect against predators while Bermectine exhibited a slight effect.

\section{Acknowledgements}

The author is grateful to Prof. Dr. Ramzy Sherif for reviewing and valuable comments on the manuscript. Thanks are also due to Prof. Dr. Ahmad S. Hendawy for identifying the surveyed spiders. 
El- Fakharany, Sanaa K. M.

4

894 


\section{REFERENCES}

Abo-Sholoa, M. K. (2001). The simultaneous effect of certain predators and three climatic factors on the population densities of some cotton pests infesting Giza 89 cotton variety at Kafr El-Shiekh. Egypt, J. Appl. Sci., $16(3): 251-268$.

El-Bessomy, M. A. E. ; M. A. M. El-Khawalka ; H. I. H. Omar and H. M. ElMaghraby (1997). Effect of the fungal insecticide (Biofly) compared with chemical in controlling different stages of whitefly Bemisia tabaci (Genn.) and its related virus. Egypt J. Agric. Res., 75 (4) : 915-921.

El-Fakharany, S. K. M. (2005). Integrated control of some vegetable crops pests in Kafr El- Sheikh province. Ph. D. Thesis, Fac. Agric., Kafr ElSheikh, Tanta Univ., pp 170.

El-Naggar, J. B. ; R. A. A. El-Doksh and S. A. Aref (2006). Efficiency of some compounds and some weather factors on some piercing sucking insects and their associated natural predators in cotton fields. J. Agric. Sci., Mansoura Univ., 31(4) : 2405-2413.

Farrag, R. M. and E. A. Zakzouk (2000). Relative abundance of some pests and their control on some host plants. Egypt J. Agric. Res., 78 (5) :1897- 1905.

Hamdy, M. K. and M. Salem (1994).The effect of plantation dates of onion, temperature and relative humidity on the population density of the onion thrips, Thrips tabaci Lind. in Egypt. Annais Agric. Sci., AinShams Univ., Cairo, 39 (1) : 417- 424.

Henderson, C. F. and E. W. Telton (1955). Test with acaricides against the brown wheat mite. J. Econ. Entomol., 48 : 157-161.

Hook, C. R. R. ; H. R. Valenzuela and J. Defrank (1998). Incidence of pests and arthropod natural enemies in zucchini grown with living mulches. Agrc. Ecosy. Enviro., $69: 217-231$.

Horowitz, A. R. (1986). Population dynamics of Bemisia tabaci (Gennadius) : with special emphasis on cotton fields. Agric. Ecosy. Enviro., $17: 37-$ 47.

Horowitz, A. R. ; Z. Mendelson and I. Ishaaya (1997). Effect of abamectin mixed with mineral oil on the sweetpotato whitefly (Homoptera : Aleyrodidae ) . J. Econ. Entomol., 90 (2) : 349 - 353.

Ibrahim, S. M. F. (2002). Effect of climatic factors on the common pests infesting mungbean plants in Alexandria, Egypt. J. Adv. Agric. Res., 7 (2) : $405-422$.

Ibrahim, N. D. and A. A. Adesiyun (2009). Effects of staggered planting dates on the control of Thrips tabaci Lindeman and yield of onion in Nigeria. African. J. Agric. Res., 4 (1) : 033 - 039.

Ismail, I. I. ; R. A. K. Salama ; S. A. Emara and I. S. Abd El-Wahab (1998). Impact of certain insecticides on the infestation levels of certain cotton sucking insect pests. Bull. Ent. Soc. Egypt Econ., 23 (117): 253 - 256.

Kimberly, A. S. and M. S. Anthony (1988). Effect of winter storage on thrips damage to cabbage. J. ISSN, 0362- 0069, 121. 
Leite, G. L. D. ; M. Picanco ; G. N. Jham and M. D. Moreira (2005). Bemisia tabaci, Brevicoryne brassicae and Thrips tabaci abundance on Brassica oleracea var. acephala . Pesq. Agropee. Bras. Brasilia,40 (3) : $197-202$.

Leite, G. L. D. ; M. Picanco ; G. N. Jham and M. D. Moreira (2006). Whitefly, aphids and thrips attack on cabbage. Pesq. Agropee. Bras. Brasilia, 41 (10) : $1469-1475$.

Mahmoud, F. M. and M. A. M. Osman (2007). Relative toxicity of some biorational insecticides to second instar larvae and adults of onion thrips (Thrips tabaci Lind.) and their predator Orius albidipennis under laboratory and field conditions. J. Plant Protect. Res., 47 (4) : 391- 400.

Mahmoud, M. F. ; M. A. M. Osman ; I. M. Bahgat and G. A. El-Kady ( 2009). Efficiency of spinetoram as biopesticide to onion thrips (Thrips tabaci Lindeman) and green peach aphid (Myzus persicae Sulzer) under laboratory and field conditions. J. Biopesticides, 2 (2) : $223-227$.

Nassef, A. M. A. ; G. A. El-Mezayyen ; G. N. Gamieh and R. M. Y. Helal (2000). Population dynamics of some sucking pests on cotton, eggplant, sweet potato and squash in relation with predatory mite and some plant components. J. Agric. Res., Tanta Univ., 26 (4) : 663 675.

Omar, B. A. and M. I. El -Kholy (2001). Comparative bio-efficacy of certain traditional and non- traditional insecticides against thrips infesting onion. J. Agric. Sci., Mansoura Univ., 26 ( 4) : 2373 - 2381.

Seham, S. El. G. ; K. M. Adam and M. A. Bachatly (1997). Effect of the planting date of tomato on the population density of Bemisia tabaci (Genn.) and Heliothis armigera (Hb.), viral infection and yield. J. Agric. Sci., Ain-Shams Univ., Cairo, 5 (1) : 135 - 144.

Sharaf, F. H. ; S. A. El-Basyouni and A. M. Hamid (2003). Insecticidal efficiency of some chemical compounds on the whitefly, Bemisia tabaci ( Gennad.) infesting cotton plants and its associated natural enemies. J. Agric. Sci., Mansoura Univ., 28 (2) : 1419 - 1423.

Thungrabeab, M. ; P. Blaeser and C. Sengonca (2006). Possibilities for biocontrolof the onion thrips Thrips tabaci Lindeman (Thysanoptera :Thripidae) using different entomopathogenic fungi from Thailand. Mitt. Deutsch. Ges. Allg. Angew. Ent., 15 : 299 - 304. 


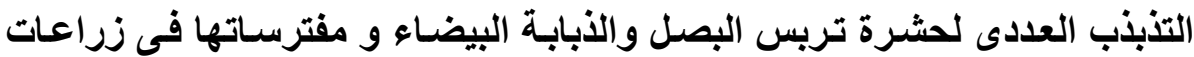

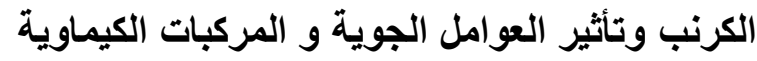

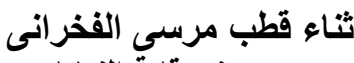

$$
\begin{aligned}
& \text { معهد بحوث وقاية النباتات ــ مركز البحوث الزراعية ـ الدقى ـ الجيزة ـ مصر }
\end{aligned}
$$

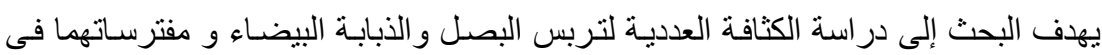

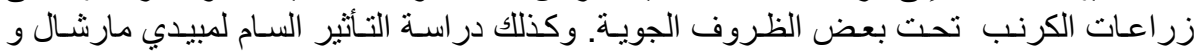

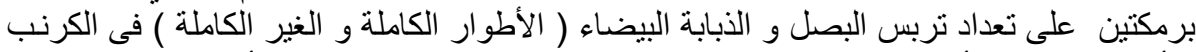

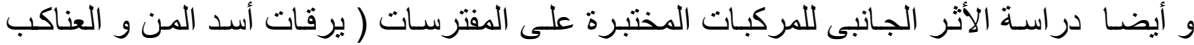

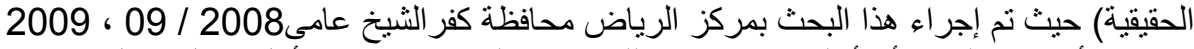

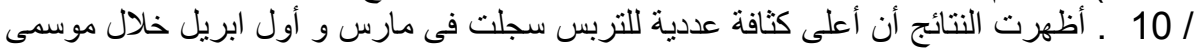

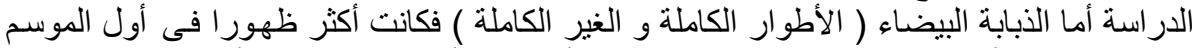

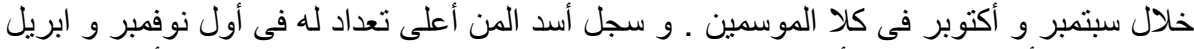

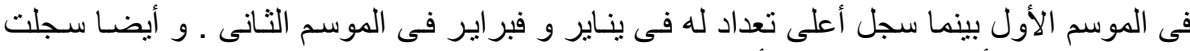

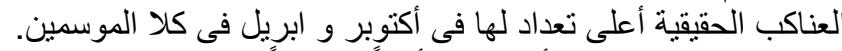

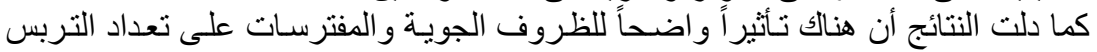

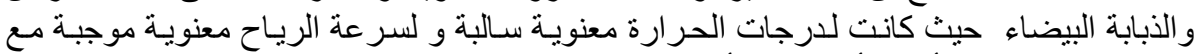

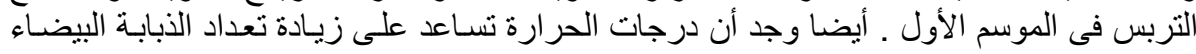

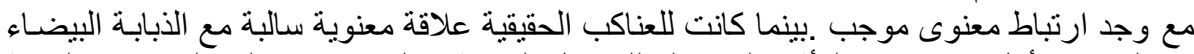

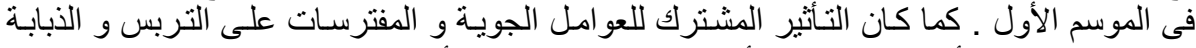

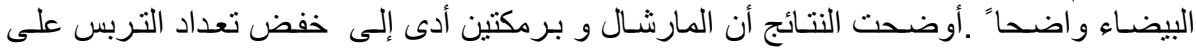

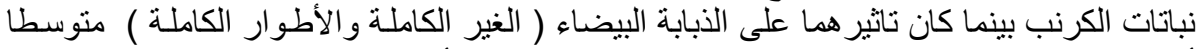

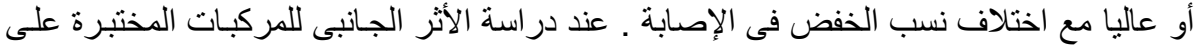

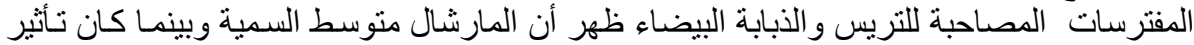
برمكتين طفيف جدا على ( أسد المن و العناكب الحقيقية ).

كلية الزراعة - جامعة المنصورة

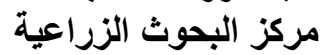

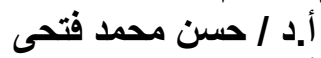

أ.د / محمود عبد المجيد محمد سامى فحى 
El- Fakharany, Sanaa K. M. 
J. Plant Prot. and Path., Mansoura Univ., Vol. 1 (11): 885 - 897, 2010

Table (2): Potency of Marshal and Bermectine in reducing Thrips tabaci populations on cabbage plants at El- Riad district, Kafr El- Sheikh Governorate.

\begin{tabular}{|c|c|c|c|c|c|c|c|c|c|c|c|}
\hline \multirow{3}{*}{ Compound } & \multirow{3}{*}{$\begin{array}{c}\text { Rate/ } \\
100 \text { liter of } \\
\text { water }\end{array}$} & \multirow{3}{*}{ 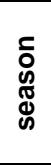 } & \multirow{3}{*}{$\begin{array}{l}\text { Number pre- } \\
\text { treatment /10 } \\
\text { leaves }\end{array}$} & \multicolumn{8}{|c|}{$\%$ Reduction } \\
\hline & & & & \multirow{2}{*}{$\begin{array}{c}\text { Initial } \\
\text { effect \% }\end{array}$} & \multicolumn{5}{|c|}{ Residual effect after indicated days } & \multirow{2}{*}{$\begin{array}{c}\text { Residual } \\
\text { effect } \\
\text { average }\end{array}$} & \multirow{2}{*}{$\begin{array}{l}\text { Grand } \\
\text { average }\end{array}$} \\
\hline & & & & & 3 & 5 & 7 & 10 & 14 & & \\
\hline \begin{tabular}{|l|} 
Pesticide \\
Marshal \\
Biopesticide
\end{tabular} & $150 \mathrm{~g}$ & $\stackrel{8}{\circ}$ & 106.50 & 99.57 & 98.51 & 97.66 & 95.63 & 93.84 & 88.60 & 94.85 & 95.64 \\
\hline $\begin{array}{l}\text { Bermectine } \\
\text { Untreated }^{\star}\end{array}$ & $\begin{array}{c}40 \mathrm{ml} \\
-\end{array}$ & ণั & $\begin{array}{c}98.50 \\
102.50 \\
\end{array}$ & $\begin{array}{c}99.41 \\
105.00 \\
\end{array}$ & $\begin{array}{c}97.95 \\
133.75 \\
\end{array}$ & $\begin{array}{c}97.18 \\
142.75 \\
\end{array}$ & $\begin{array}{c}96.17 \\
145.50 \\
\end{array}$ & $\begin{array}{c}94.29 \\
156.25 \\
\end{array}$ & $\begin{array}{c}90.01 \\
155.75 \\
\end{array}$ & $\begin{array}{c}95.12 \\
-\end{array}$ & $\begin{array}{c}95.84 \\
-\end{array}$ \\
\hline $\begin{array}{l}\text { Pesticide } \\
\text { Marshal } \\
\text { Biopesticide }\end{array}$ & $150 \mathrm{~g}$ & $\frac{0}{2}$ & 225.00 & 99.82 & 99.82 & 98.38 & 97.35 & 93.67 & 89.78 & 95.80 & 96.47 \\
\hline $\begin{array}{l}\text { Bermectine } \\
\text { Untreated }^{\star}\end{array}$ & $\begin{array}{c}40 \mathrm{ml} \\
-\end{array}$ & ర్సి & $\begin{array}{l}214.25 \\
207.75 \\
\end{array}$ & $\begin{array}{r}99.81 \\
210.50 \\
\end{array}$ & $\begin{array}{r}99.81 \\
216.00 \\
\end{array}$ & $\begin{array}{c}98.07 \\
221.25 \\
\end{array}$ & $\begin{array}{r}97.06 \\
221.75 \\
\end{array}$ & $\begin{array}{c}94.21 \\
235.00 \\
\end{array}$ & $\begin{array}{r}91.53 \\
202.50 \\
\end{array}$ & $\begin{array}{c}96.14 \\
- \\
\end{array}$ & $\begin{array}{c}96.75 \\
- \\
\end{array}$ \\
\hline
\end{tabular}

* Numbers 


\section{El- Fakharany, Sanaa K. M.}

Table (3): Potency of Marshal and Bermectine in reducing Bemisia tabaci populations on cabbage plants at El-Riad district, Kafr El-Sheikh Governorate.

\begin{tabular}{|c|c|c|c|c|c|c|c|c|c|c|c|}
\hline \multirow{3}{*}{ Compound } & \multirow{3}{*}{$\begin{array}{c}\text { Rate/ } \\
100 \text { liter } \\
\text { of water }\end{array}$} & \multirow{3}{*}{ 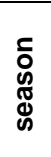 } & \multirow{3}{*}{$\begin{array}{l}\text { Number pre- } \\
\text { treatment } / 10 \\
\text { leaves }\end{array}$} & \multicolumn{8}{|c|}{$\%$ Reduction } \\
\hline & & & & \multirow{2}{*}{$\begin{array}{c}\text { Initial } \\
\text { effect \% }\end{array}$} & \multicolumn{5}{|c|}{ Residual effect after indicated days } & \multirow{2}{*}{$\begin{array}{c}\text { Residual } \\
\text { effect } \\
\text { average }\end{array}$} & \multirow{2}{*}{$\begin{array}{c}\text { Grand } \\
\text { average }\end{array}$} \\
\hline & & & & & 3 & 5 & 7 & 10 & 14 & & \\
\hline \multicolumn{12}{|c|}{ Adult } \\
\hline \begin{tabular}{|l|} 
Pesticide \\
Marshal
\end{tabular} & $150 \mathrm{~g}$ & $\stackrel{2}{\circ}$ & 160.00 & 83.50 & 77.01 & 69.00 & 64.50 & 60.20 & 52.50 & 64.64 & 67.79 \\
\hline $\begin{array}{l}\text { Biopesticide } \\
\text { Bermectine } \\
\text { Untreated }^{\star}\end{array}$ & $\begin{array}{c}40 \mathrm{ml} \\
-\end{array}$ & ֻั & $\begin{array}{l}142.25 \\
100.25\end{array}$ & $\begin{array}{c}70.01 \\
120.00\end{array}$ & $\begin{array}{c}75.00 \\
137.00\end{array}$ & $\begin{array}{c}77.00 \\
140.25\end{array}$ & $\begin{array}{c}67.00 \\
150.00\end{array}$ & $\begin{array}{c}62.20 \\
169.50\end{array}$ & $\begin{array}{c}60.20 \\
180.00\end{array}$ & $\begin{array}{c}68.28 \\
-\end{array}$ & $\begin{array}{c}68.57 \\
-\end{array}$ \\
\hline \begin{tabular}{|l|} 
Pesticide \\
Marshal \\
Biopesticide
\end{tabular} & $150 \mathrm{~g}$ & $\frac{0}{8}$ & 196.25 & 81.40 & 74.20 & 70.00 & 61.90 & 58.50 & 49.20 & 62.76 & 65.87 \\
\hline $\begin{array}{l}\text { Bermectine } \\
\text { Untreated }^{*}\end{array}$ & $\begin{array}{c}40 \mathrm{ml} \\
- \\
\end{array}$ & ఫ్సి & $\begin{array}{l}189.75 \\
164.00 \\
\end{array}$ & $\begin{array}{r}69.80 \\
169.50 \\
\end{array}$ & $\begin{array}{c}72.00 \\
172.00 \\
\end{array}$ & $\begin{array}{c}75.00 \\
177.00\end{array}$ & $\begin{array}{c}65.50 \\
180.00\end{array}$ & $\begin{array}{c}59.40 \\
181.00\end{array}$ & $\begin{array}{c}55.50 \\
190.00\end{array}$ & $\begin{array}{c}65.48 \\
-\end{array}$ & $\begin{array}{c}66.20 \\
-\end{array}$ \\
\hline \multicolumn{12}{|c|}{ Immature (nymphs and pupae ) } \\
\hline \begin{tabular}{|l} 
Pesticide \\
Marshal \\
Biopesticide
\end{tabular} & $150 \mathrm{~g}$ & 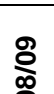 & 111.00 & 84.00 & 81.50 & 73.00 & 71.90 & 65.20 & 61.40 & 70.60 & 72.83 \\
\hline $\begin{array}{l}\text { Bermectine } \\
\text { Untreated }^{\star}\end{array}$ & $\begin{array}{c}40 \mathrm{ml} \\
- \\
\end{array}$ & ఫ్ & $\begin{array}{l}97.00 \\
76.25 \\
\end{array}$ & $\begin{array}{l}75.00 \\
80.00 \\
\end{array}$ & $\begin{array}{l}81.20 \\
85.00 \\
\end{array}$ & $\begin{array}{l}82.00 \\
93.00\end{array}$ & $\begin{array}{l}79.00 \\
99.00\end{array}$ & $\begin{array}{c}69.80 \\
108.00\end{array}$ & $\begin{array}{c}62.50 \\
117.00\end{array}$ & $\begin{array}{c}74.90 \\
-\end{array}$ & $\begin{array}{c}74.92 \\
-\end{array}$ \\
\hline \begin{tabular}{|l} 
Pesticide \\
Marshal \\
Biopesticide
\end{tabular} & $150 \mathrm{~g}$ & 웅 & 84.00 & 84.50 & 80.60 & 70.90 & 68.50 & 62.20 & 59.80 & 68.40 & 71.08 \\
\hline $\begin{array}{l}\text { Bermectine } \\
\text { Untreated }^{*}\end{array}$ & $40 \mathrm{ml}$ & ర్సి & $\begin{array}{c}101.00 \\
79.00\end{array}$ & $\begin{array}{l}74.00 \\
99.00\end{array}$ & $\begin{array}{c}79.80 \\
104.00\end{array}$ & $\begin{array}{c}80.50 \\
111.00\end{array}$ & $\begin{array}{c}73.20 \\
115.00\end{array}$ & $\begin{array}{c}65.40 \\
120.00\end{array}$ & $\begin{array}{c}60.08 \\
121.00\end{array}$ & 71.79 & $\begin{array}{c}72.16 \\
-\end{array}$ \\
\hline
\end{tabular}

$$
{ }^{*} \text { Numbers }
$$


J. Plant Prot. and Path., Mansoura Univ., Vol. 1 (11), November, 2010

Table (4): Potency of tested compounds in reducing predators populations on cabbage plants at El- Riad district, Kafr El- Sheikh Governorate.

\begin{tabular}{|c|c|c|c|c|c|c|c|c|c|c|c|}
\hline \multirow{3}{*}{ Compound } & \multirow{3}{*}{$\begin{array}{c}\text { Rate/ } \\
100 \text { liter of } \\
\text { water }\end{array}$} & \multirow{3}{*}{ 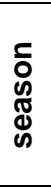 } & \multirow{3}{*}{$\begin{array}{c}\text { Number pre- } \\
\text { treatment } / 10 \\
\text { plants }\end{array}$} & \multicolumn{8}{|c|}{ \% Reduction } \\
\hline & & & & \multirow{2}{*}{$\begin{array}{c}\text { Initial } \\
\text { effect \% }\end{array}$} & \multicolumn{5}{|c|}{ Residual effect after indicated days } & \multirow{2}{*}{$\begin{array}{c}\text { Residual } \\
\text { effect } \\
\text { average }\end{array}$} & \multirow{2}{*}{$\begin{array}{c}\text { Grand } \\
\text { average }\end{array}$} \\
\hline & & & & & 3 & 5 & 7 & 10 & 14 & & \\
\hline $\begin{array}{l}\text { Pesticide } \\
\text { Marshal }\end{array}$ & $150 \mathrm{~g}$ & $\stackrel{?}{\circ}$ & 15.00 & 50.00 & 45.50 & 37.02 & 29.29 & 16.50 & 6.92 & 27.05 & 30.87 \\
\hline $\begin{array}{l}\text { Biopesticide } \\
\text { Bermectine } \\
\text { Untreated }^{\star}\end{array}$ & $40 \mathrm{ml}$ & :্ণ & $\begin{array}{l}13.50 \\
14.00\end{array}$ & $\begin{array}{l}13.00 \\
16.00\end{array}$ & $\begin{array}{c}2.75 \\
18.75\end{array}$ & $\begin{array}{l}00.00 \\
19.50\end{array}$ & $\begin{array}{l}00.00 \\
20.25\end{array}$ & $\begin{array}{l}00.00 \\
22.75\end{array}$ & $\begin{array}{l}00.00 \\
25.50\end{array}$ & 0.55 & $\begin{array}{c}2.63 \\
-\end{array}$ \\
\hline $\begin{array}{l}\text { Pesticide } \\
\text { Marshal } \\
\text { Biopesticide }\end{array}$ & $150 \mathrm{~g}$ & $\frac{0}{5}$ & 14.50 & 55.00 & 49.00 & 39.00 & 32.00 & 17.00 & 5.01 & 28.40 & 32.84 \\
\hline Bermectine & $40 \mathrm{ml}$ & 오 & 12.75 & 14.25 & 4.00 & 0.50 & 00.00 & 00.00 & 00.00 & .90 & 3.13 \\
\hline Untreated ${ }^{\star}$ & & & 13.00 & 13.75 & 15.00 & 17.25 & 19.00 & 19.25 & 24.00 & - & - \\
\hline
\end{tabular}

* Numbers

predators : Chrysoperla carnea and true spiders 